\title{
EVALUATION OF PARTICLES SIZE DURING THE COMBUSTION OF BIODIESEL AND OPTIMIZER ADDITIVE IN A COMPRESSION IGNITION ENGINE
}

Pedro Bancillon Ventin Muniza,b, Felipe Andrade Torres ${ }^{b, c}$, Clara Rodrigues Pereira ${ }^{a}$, Júlio César Chaves Câmara ${ }^{a}$, Ednildo Andrade Torres ${ }^{b}$, Lílian Lefol Nani Guarieiro ${ }^{a}$

a SENAI CIMATEC, Brazil,

b PEI/UFBA, Brazil,

${ }^{c}$ UFRB, Brazil.

\begin{abstract}
Biofuels have been long term considered in blends with mineral diesel aiming to reduce particulate matter (PM) emissions in diesel engines. In this context, biodiesel is one of the most promising biofuels, although optimizer additives are also considered to further reduce PM emissions. This work presents the results of an evaluation of the particle number and size distribution (PSD) emitted by a diesel engine fueled with mineral diesel, biodiesel and an optimizing additive. This additive aims to reduce the number of particles emitted, which advantages the use of biofuel in a diesel engine. This comparative study has shown that the addition of biodiesel to mineral diesel induces an increase in peak PM emissions and the additive was able to reduce emissions for the biodiesel mixture within the engine conditions tested.
\end{abstract}

Keywords: Biodiesel; Optimizer Additive; Particle Size Distribution; Diesel engine.

\section{AVALIAÇÃO DO TAMANHO DE PARTÍCULAS DURANTE A COMBUSTÃO DE BIODIESEL E ADITIVO OTIMIZADOR EM UM MOTOR DE IGNIÇÃO POR COMPRESSÃO}

Resumo: Os biocombustíveis têm sido considerados há muito tempo em misturas com diesel mineral com o objetivo de reduzir as emissões de partículas (PM) em motores a diesel. Nesse contexto, o biodiesel é um dos biocombustíveis mais promissores, embora aditivos otimizadores também sejam considerados para reduzir ainda mais as emissões de PM. Este trabalho apresenta os resultados de uma avaliação da distribuição do tamanho e número de partículas (PSD) emitida por um motor diesel movido a diesel mineral, biodiesel e aditivo otimizador. Esse aditivo tem como objetivo reduzir o número de partículas emitidas, o que beneficia o uso do biocombustível em motor diesel. Este estudo comparativo mostrou que a adição de biodiesel ao diesel mineral induz um aumento do pico de emissões de MP e o aditivo foi capaz de reduzir emissões para a mistura de biodiesel nas condições do motor.

Palavras-chave: Biodiesel; Aditivo Otimizador; Distribuição do Tamanho de Partículas; Motor diesel. 


\section{INTRODUCTION}

The partial or total substitution of diesel for biodiesel has brought some drawbacks such as an increase in nitrogen oxides, specific fuel consumption [1], and the emission of particulate material in some cases (PM) [2]. Combustion-optimizing additives (i.e. catalysts) have proven to be promising solutions when associated with diesel or biodiesel, as they minimize these unwanted effects [3] while provides a further contribution in reducing particulate matter (PM) [2]. Additives, usually in liquid solutions, have advantages in their use, as they do not require structural or operational modifications of the diesel engine.

Catalysts may be classified into several categories, each of which has a focus on optimizing engine operation characteristics. The main ones are listed below in Table 1:

Table 1. Catalyst specifications and respective technical features.

\begin{tabular}{|c|c|}
\hline Catalyst & Technical Features \\
\hline Metal-based additives & $\begin{array}{c}\text { These additives are generated through metallic } \\
\text { nanoparticles and the main objective is to } \\
\text { promote a reduction of hydrocarbons through a } \\
\text { reaction involving water vapors, metals, and } \\
\text { exhaust gases [4]. }\end{array}$ \\
\hline Antioxidant additives & $\begin{array}{c}\text { These are additives used in fuel storage aiming } \\
\text { to reduce its oxidation [3]. }\end{array}$ \\
\hline Lubrication-optimizing additives & $\begin{array}{l}\text { Lubrication-enhancing additives aim to produce } \\
\text { a protective film on metal surfaces that come } \\
\text { into contact with diesel fuel [3]. }\end{array}$ \\
\hline Cetane number improving additives & $\begin{array}{l}\text { Cetane improvers, as the name suggests, } \\
\text { promotes the increasing the number of cetanes } \\
\text { presented in diesel or blends biodiesel and } \\
\text { diesel. This improvement is usually associated } \\
\text { with decrease in soot emission [5]. }\end{array}$ \\
\hline Additives of oxygenated solutions & $\begin{array}{l}\text { This class is the most researched since it } \\
\text { includes the use of oxygenated fuels } \\
\text { associated with diesel and biodiesel, especially } \\
\text { alcohol. The addition of oxygenated fuels may } \\
\text { provide a reduction in emissions since the } \\
\text { higher oxygen content in the mixture may } \\
\text { contribute to the reduction of temperature } \\
\text { peaks in the combustion chamber [5]. }\end{array}$ \\
\hline
\end{tabular}

The particle size distribution (PSD) evaluates the PM emission an engine based on the concentration number and diameter of the particles. These particles are classified by types, whereas: the coarse ones present an average in the aerodynamic 
diameter (dp) between 2.5 to $10 \mu \mathrm{m}$; the fine particles have values between $2.5 \mu \mathrm{m}$ at $100 \mathrm{~nm}$, while the ultrafine ones (including nanoparticles) are classified with the dp below $100 \mathrm{~nm}$. The concern with the emitted particles involve the probable cardiorespiratory diseases linked to the compounds emitted by diesel since these have the capacity to penetrate the pulmonary alveoli, which may lead to the appearance of cancer [6]. The analysis of experiments showed that some additives provide a reduction in coarse and fine particles, as well as an increase in ultrafine and nanoparticles [2]. A study involving metallic catalysts indicated reductions in coarse particles [7]. In an experiment evaluating the insertion of hydrogen as an additive, the results demonstrated a reduction in fine particles and an increase in coarse particles [8].

The additives are supplied in the fuel tank of a diesel engine and aim at improving the combustion properties, generating a lower emission of gaseous pollutants, greater energy and power generated, less fuel consumption and a reduction in the number of particles emitted [7]. The focus of this work was to evaluate the behavior of an additive based on the emission of the number of particles through a diesel engine stationary regime. Studies involving catalyst enzymes are not common, so the objective of this experiment is to evaluate the emission of particles from a compression ignition engine using commercial biodiesel and commercial biodiesel with additives.

\section{METHODOLOGY}

The experiments of this study were carried out using a Schenk hydraulic dynamometer, model D - 210/1-E. This dynamometer was coupled to an Agrale M-790 compression ignition engine. Table 2 shows the main specifications of the engine.

Table 2. Test engine specifications.

\begin{tabular}{|l|c|}
\hline Model & Agrale M-790 \\
\hline Swept volume ${\left(\mathbf{L}^{3}\right)}^{\mathbf{3}}$ & 1.3 \\
\hline Number of cylinders & 2 \\
\hline Stroke type & Four-stroke \\
\hline Compression ratio & $18: 1$ \\
\hline Position of cylinders & Vertical \\
\hline Turbocharged & No \\
\hline Fuel Injection system & Direct \\
\hline Max Torque & 70 N.m @ 2250 rpm \\
\hline Max power & $30 \mathrm{cv} / 22 \mathrm{~kW} @ 3000 \mathrm{rpm}$ \\
\hline Engine Cooling system & Air \\
\hline
\end{tabular}


The particle number distribution analysis was assessed with a TSI Nanoscam 3910 spectrometer, which was coupled to a constant volume sampling (CVS) dilution tunnel. The tunnel was utilized to dilute part of atmospheric air to the emission gases, to extract the values emitted from the engine. The same dilution ratio $(24: 1)$ of atmospheric air and engine emission gases was used for the tests. Figure 1 shows a schematic diagram of the test set up.

Figure 1. Scheme diagram of the experimental set-up.

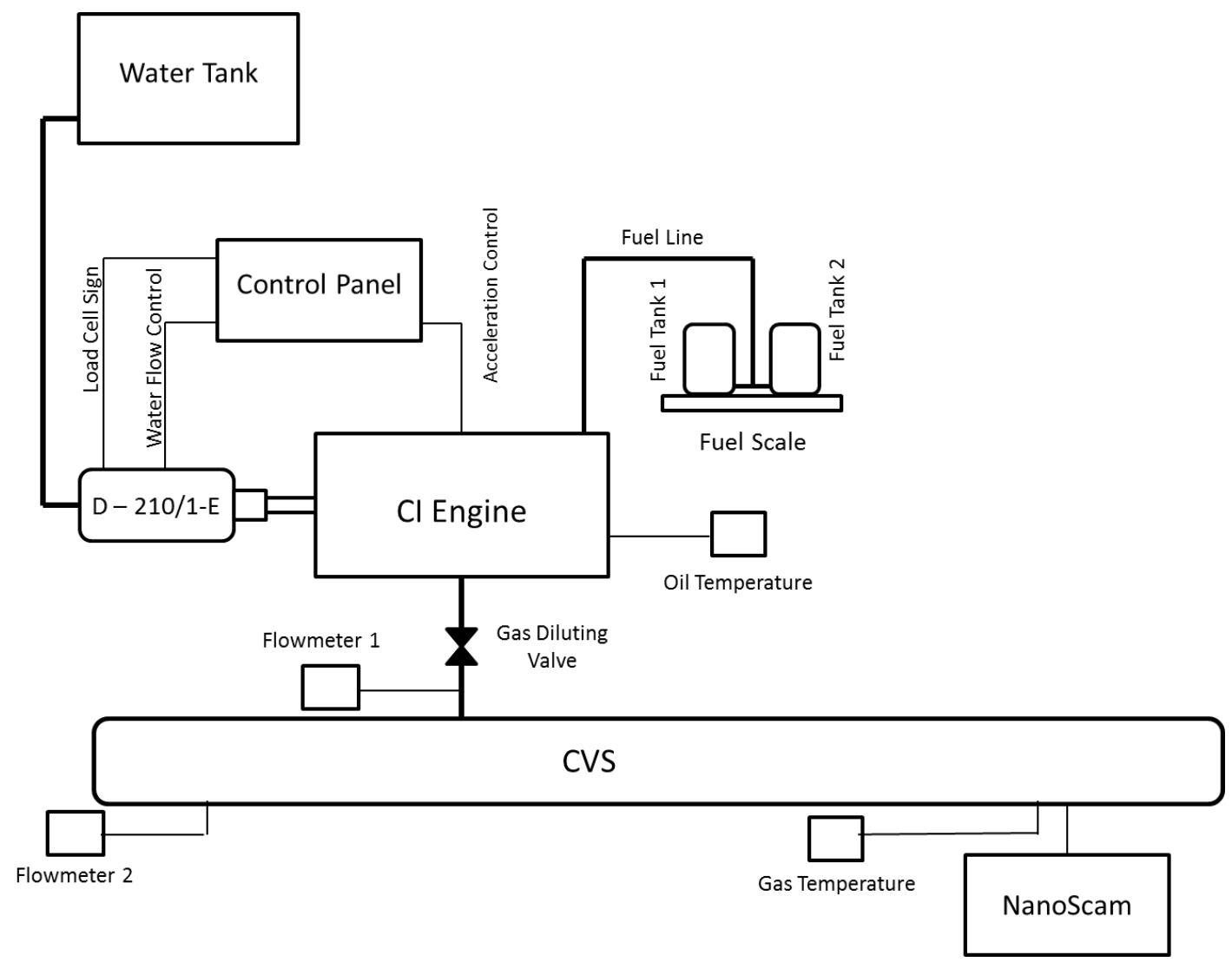

Three fuels were tested, a mineral diesel without biodiesel or additive (B0), a commercial diesel with $11 \%$ of biodiesel but without additive (B11), and commercial diesel with $11 \%$ biodiesel and with additives (B11x). All fuels have a concentration of $10 \mathrm{ppm}$ of sulfur. Mineral diesel was donated by PetroBahia. The commercial diesel fuel was purchased at a gas station in the city of Salvador - BA. The additive was added to the fuel in a concentration of $10 \mathrm{ppm}$ as indicated by the manufacturer. The soluble additive is composed of approximately 20 different types of enzymes that, when dissolved, create a chain of biochemical reactions providing a more complete fuel combustion, generating less polluting gases and optimizing the combustion energy. Some specifications and properties of the tested fuels are shown in table 3.

Table 3. Fuel Specifications 


\begin{tabular}{|c|c|c|c|c|c|}
\hline Fuel property & Unit & Method & BO & B11 & $\begin{array}{l}\text { B11x (with } \\
\text { additive) }\end{array}$ \\
\hline $\begin{array}{l}\text { Biodiesel } \\
\text { concentration }\end{array}$ & Volume $\%$ & - & 0 & 11 & 11 \\
\hline Density & $\mathrm{kg} / \mathrm{m}^{3}$ & NBR 7148 & 833.1 & 839.1 & 839.3 \\
\hline $\begin{array}{l}\text { Kinematic } \\
\text { viscosity }\end{array}$ & cSt & NBR 10441 & 3.63 & 3.84 & 3.68 \\
\hline Water content & $\mathrm{mg} / \mathrm{kg}$ & KF & 433.3 & 333.3 & 500 \\
\hline
\end{tabular}

The test was performed under constant engine speed and load, $1700 \mathrm{rpm}( \pm$ $10)$ and 15 N.m $( \pm 1)$ respectively. This operational condition generated an engine power break of $2.7 \mathrm{~kW}$, according to equation 1 .

$$
\dot{W}=T \cdot R P M \cdot\left(\frac{2 \cdot \pi}{60000}\right)
$$

The equipment was kept in operation until it reached its optimum working temperature. After reaching the values indicated by the manufacturer, the spectrometer was turned on and kept in operation for about 5 minutes for each of the fuels tested. The measuring range of the equipment was configured in order to measure the particle concentration with diameters between a range of 10 to $400 \mathrm{~nm}$. After collecting the results, the data for each concentration was multiplied by the system dilution ratio and treated by the Grubbs's test.

\section{RESULTS AND DISCUSSION}

The results of the spectrophotometer analysis were grouped and demonstrated on a logarithmic basis for easier-comprehension. Through this analysis, it is possible to notice that all fuels have a clear modal trend in the range of 50 to $120 \mathrm{~nm}$, which is in accordance with the literature $[2,5,6]$.

Moreover, mineral diesel without the presence of biodiesel (B0) has shown the same emission of fine and ultrafine particles in comparison of all the tested fuels, and its peak emission occurred in the aerodynamic diameter of $64.9 \mathrm{~nm}$.

When adding biodiesel to the mineral diesel (B11 fuel), it was observed an increase of particles emitted after the peak diameter (excluding the diameter ranges of 86.6 and 115.5). This increase is maintained until the end of the equipment's reading range. B11 showed a peak emission in the $64.9 \mathrm{~nm}$ range, similar to $\mathrm{B} 0$, although twice as many particles emitted. This behavior is reported by other researchers in their experiments and analyzes [2].

The additive combined to B11 (B11x fuel) provided a significant reduction in the peak concentration and the diameter range after $154 \mathrm{~nm}$ of particles emitted by the 
biodiesel blend. The catalyst maintained its peak emission in around $64.9 \mathrm{~nm}$, but reduced the emitted values by approximately $25 \%$. Further, at some ranges, the values were statistically equal to B11 and B0. In summary, the additive did show particle reductions for the experiment carried out according to figure 2 .

Figure 2. Effect of fuels on PSD at 15 N.m. and 1700 rpm.

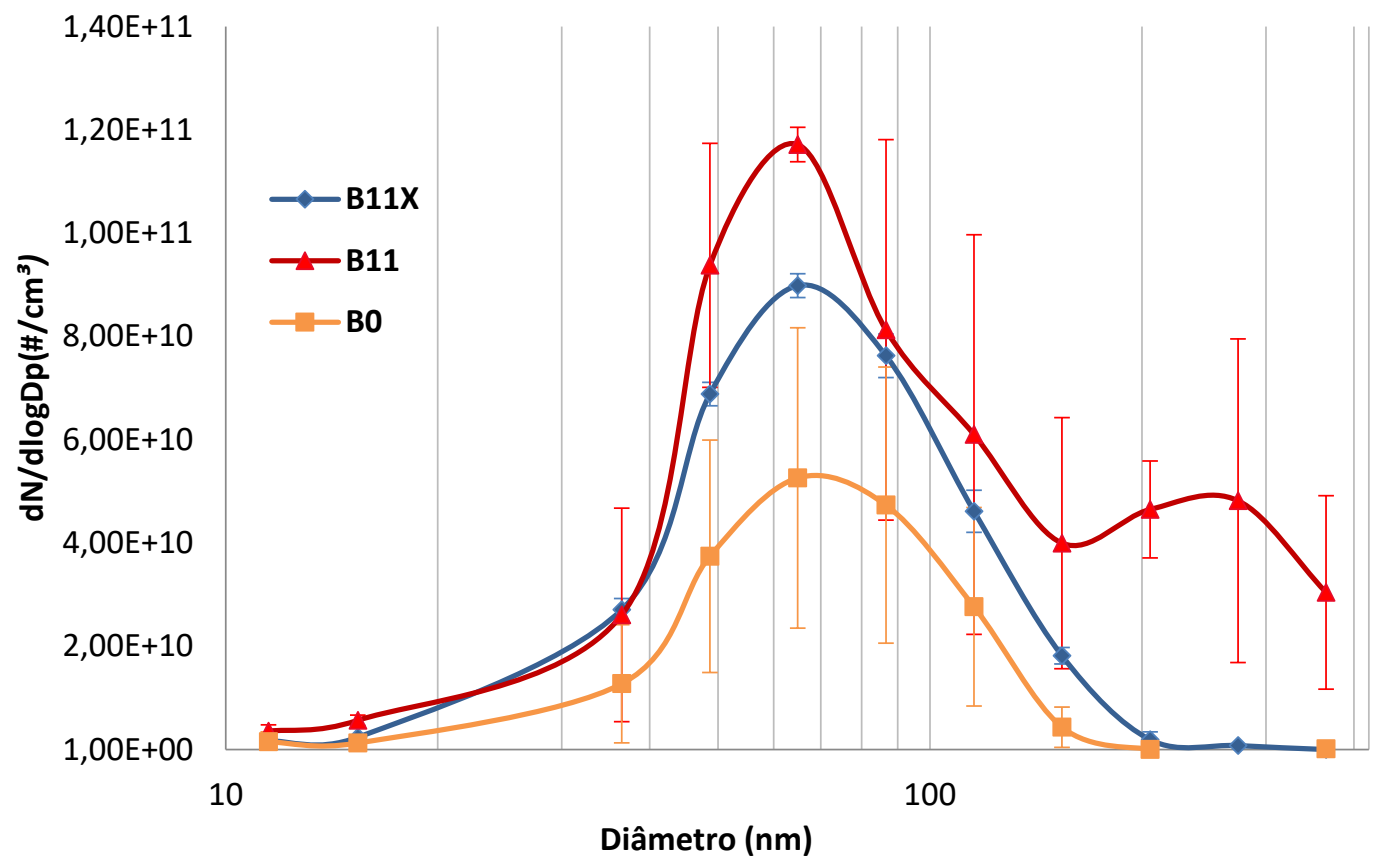

\section{CONCLUSION}

Based on the analysis of the experimental data, it is possible to identify that when adding biodiesel to the mineral diesel the concentration number of fine particles are increased, while the nano and ultrafine particles remained statistically the same for all tested fuels.

The behavior of the mixture with additive showed reductions in the particles emission under the analyzed engine conditions and in the tested additive concentration. Considering the reports in the previous literature, a new round of tests must be carried out to verify the behavior of the catalyst for different engine conditions and additive concentrations.

\section{REFERENCES}


${ }^{1}$ AGARWAL, A.K. et al. Potential and challenges for large-scale application of biodiesel in automotive sector. Progress in Energy and Combustion Science, v. 61, p. 113-149, 2017.

${ }^{2}$ GUARIEIRO, L. et al. Assessment of the Use of Oxygenated Fuels on Emissions and Performance of a Diesel Engine. Microchemical Journal, v. 117, p. 94-99, 2014 ${ }^{3}$ RASHEDUL, H.K. et al. The effect of additives on properties, performance and emission of biodiesel fuelled compression ignition engine. Energy Conversion and Management, v. 88, p. 348-364, 2014.

${ }^{4}$ MIRZAJANZADEH, M. et al. A novel soluble nano-catalysts in diesel-biodiesel fuel blends to improve diesel engines performance and reduce exhaust emissions. Fuel, v. 139, p. 374-382, 2015.

${ }^{5}$ VIJAY KUMAR, M. The impacts on combustion, performance and emissions of biodiesel by using additives in direct injection diesel engine. Alexandria Engineering Journal, v. 57, p. 509-516, 2018.

${ }^{6}$ LAPUERTA, Magin. et al. Effect of biodiesel fuels on diesel engine emissions. Progress in Energy and Combustion Science, 34, 198-223, 2008.

${ }^{7} \mathrm{SHAAFI}, \mathrm{T}$.; VELRAJ. R. Influence of alumina nanoparticles, ethanol and isopropanol blend as additive with diesel-soybean biodiesel blend fuel: Combustion, engine performance and emissions. Renewable Energy, v. 80, p. 655-663, 2015.

8 BARRIOS, C.C. et al. Influence of hydrogen addition on combustion characteristics and particle number and size distribution emissions of a TDI diesel engine. Fuel, v. 199, p. 162-168, 2017. 